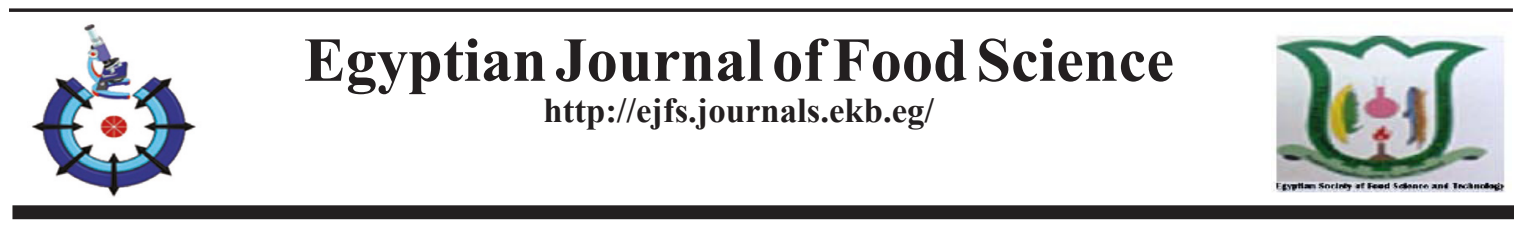

\title{
Carcass Characteristics and Nutritional Composition of Some Edible Chicken By-products
}

\author{
Shenoda G. M. Henry, Soumia M. I. Darwish, Ahmed S. M. Saleh*, Ahmed H. \\ A. Khalifa* \\ Department of Food Science \& Technology, Faculty of Agriculture, Assiut University, \\ Assiut 71526, Egypt.
}

\begin{abstract}
$\mathbf{T}$ HE objective of this study was to evaluate the characteristics of chicken carcass and determine the nutritional composition of some edible chicken by-products, including liver, gizzard, wings, and skin. The total yield of liver, gizzard, wings and skinof chicken wasfound to be about $23.43 \%$ of carcassweight. The results showed that these chicken by-products are good sources of protein, fat, and minerals (ash). The greatest protein content was found to be $26.33 \%$ (wb) for wings; while, skin showed the greatest fat content of $34.48 \%$ (wb) compared with other by-products. On the other hand, liver showed the greatest ash content of $1.42 \%(\mathrm{wb})$ and skin showed the lowest ash content of $0.46 \%$ (wb). Moreover, the greatest caloric value of $362.36 \mathrm{Kcal} / 100 \mathrm{~g}$ was found for skin, followed by wings, liver, and gizzard. In addition, the results showed good contents of potassium, phosphorus, sodium, iron, and zinc in chicken by-products. These by-products were found to be a good source of essential amino acids such as leucine and lysine. Furthermore, liver, gizzard, wings, and skin of chicken showed greater unsaturated fatty acids content than that of saturated fatty acids. Oleic, linoleic, linolenic, and arachidonic acids are the most predominant unsaturated fatty acids found in these chicken byproducts. However, palmitic and stearic acids are the predominant saturated fatty acids found in the studied chicken by-products. The obtained results revealed that the liver, gizzard, wings, and skin of chicken are rich of healthy nutrients; therefore, the utilization of these by-products as food should be promoted by development of new food products through the advances in meat processing techniques.
\end{abstract}

Keywords: Edible chicken by-products, Chemical composition, Nutritive value .

\section{Introduction}

Global meat production was expectedto increase to 336.2 million tons in 2018 , in carcass weight equivalent, 1.7 percent greater than it in 2017. Poultry meat, with the largest production since 2016, was expected to grow by 2 million tons in 2018, or 1.6 percent (FAO, 2018). On the other hand, the global demand for meat is expected to increase by about 44 percent to over 400 million tons by 2030 to meet the need of growing population. Also, poultry production is expected to be the greatest at $60 \%$, with poultry forecast up to $39 \%$ of the worldwide meat demand by 2030 and become the most consumed meat (Mulder,
2011). The annual poultry consumption is around 1.2 billion birds in Egypt, which equivalent poultry meat of 1125 million tons. In addition, the total consumption of poultry meat in Egypt is expected to increase from 993,000 tons in 2017 to 1156,000 tons in 2026 (FAO, 2017). Therefore, the poultry industry is one of the largest agricultural industries worldwide, whichisattributed to the increasing demand for poultry meat and egg products (Bolan et al., 2010).

Diet plays a major role in the human health and meat products are a major source of valuable protein in the human diets. However, fatof meat contains great amount of unsaturated and

*For Correspondence : ahmed.saleh@aun.edu.eg; hmdkhalifa@yahoo.com

Received:28/8/2019; accepted:16/9/2019

DOI: $10.21608 /$ EJFS.2019.16364.1018

(C2019 National Information and Documentation Centre (NIDOC) 
saturated fatty acids and is considereda source of cholesterol; therefore, appropriate manipulation with broiler chicken diet can modify fatty acids profile of meat and enhance its nutritional quality (Valsta et al., 2005). In addition, the increase of chicken meat consumption can be attributed to some factors such as its low costprice, easy-processing, high-nutritive value, and low-cholesterol content (Alvarez- Astorga et al., 2002; Fletcher, 2002 and Chouliara et al., 2007). Because of the high demand for chicken meat, the production of slaughtering by-products such as heart, liver, spleen, kidney, skin, andabdominal fat tissues, which count about $37 \%$ of live broilers weight, has been increased (Ockerman \& Basu, 2004 and Bimbo, 2005). Generally, the edible by-products of chicken are globally utilizedforpreparing of varying dishes. For example, the giblets of chicken are consumed in the United States of America; while, all edible chicken offal are used for making Japanese dishes in Japan. Also, the edible by-products of chicken are used in many Asian countriesfor human consumption (Nollet and Toldrá, 2011).The meat by-products utilization depends on some factors such as religion, preference, and culture. For example, some by-products those are considered inedible in a country, but they are considered as precious products in other countries (Toldra et al., 2012). Therefore, withthe growing poultry production and processing activities, availability of the edible by-products would be increased (Mountney and Parkhurst, 2001).

Gizzard is one of the main edible by-products of poultry processing, which is marketed as variety meats along with dressed chicken (Charoenpong and Chen, 1980). Also, chicken skin was found to be represented in range from 8 to $20 \%$ of the total carcass weight (Fereidoun et al., 2007).On the other hand, chicken liver is a rich source of essential amino acids, protein, zinc, and iron with low price cost (Abu-Salem \& Abou Arab, 2010 and Seong et al., 2015). During the last decades, many studies focused on chicken meat quality evaluation and processing methods. However, few studies were performed on evaluation of nutritional quality of chicken by-products (Seong et al., 2015). The edible byproducts of chickenoriginsare important in the human diets and account for a significant ratio of live weight. Therefore, studying the nutrients composition and evaluation of nutritional quality of poultry by-products is important to provide nutritional information for consumers and promote the utilization as food. The main objective of this study was to determine the nutrients composition of some edible chicken by-products, including liver, gizzard, wings, and skin.

\section{Materials and Methods}

\section{Materials}

Ten farmed chickens ( 6 weeks age, males and females),were purchasedfrom a local market at Assuit city, Egypt.

\section{Body composition and carcass characteristics measurement}

Birds were weighed and slaughtered using a sharp knife according to the Islamic method and allowed to bleed for $5 \mathrm{~min}$. The dressed carcasses were reweighed and cut into various parts, which weighed to study carcass characteristics and body composition. The wings cuts were hand deboned and the obtained meat (Liver, gizzard and skin) were minced using a meat mincer, packaged in bags of polyethylene,then kept in a freezer at $-18{ }^{\circ} \mathrm{C}$. Frozen meat was thawed overnight in a refrigerator $\left(4^{\circ} \mathrm{C}\right)$ prior to analysis.

\section{Proximate chemical composition analysis}

The proximate chemical composition of the edibleby-products of chickens was determined according to the AOAC method (2000). The Kjeldahl method was used to determine the crude protein content and Soxhlet method was used to determine the lipids content. Ashing at $550^{\circ} \mathrm{C}$ overnight was carried out to determine the ash content of samples. Samples were dried at $105^{\circ}$ $\mathrm{C}$ overnight to determine the moisture content.

\section{Caloric value calculation}

Caloric value of the studied edible chicken by-products was calculated as follows:

Caloric value $(\mathrm{kcal} / 100 \mathrm{gm})=(\%$ carbohydrate $\times 4)+(\%$ protein $\times 4)+(\%$ fat $x 9)$, as described by Mohamed (2005).

\section{Determination of minerals content}

A flam photometer 410 was used for determination of sodium and potassium contents of chicken by-products; while,spekoll 1 spectrophotometer was used for determination of phosphorus content. Contents of $\mathrm{Ca}, \mathrm{Fe}, \mathrm{Mg}$, $\mathrm{Mn}$, and $\mathrm{Zn}$ were determined by Inductively Coupled Plasma Emission Spectrometer (iCAP 6200). The determination was carried out as described by AOAC (1995). 


\section{Amino acids composition analysis}

Amino acids composition of the studied byproducts wasdetermined as described by Pellett and Young (1980). Dry and fat-free samples were weighed and hydrolyzed with $5 \mathrm{~mL}$ of $6 \mathrm{~N} \mathrm{HCl}$ in a sealed test tube at $110^{\circ} \mathrm{C}$ for $24 \mathrm{~h}$. The obtained hydrolysate was filtratedand the residue was washed with distilled water. The volume of the filtrate was adjusted to $50 \mathrm{~mL}$ with distilled water and $5 \mathrm{~mL}$ of filtrate sample was evaporated on a water bath at $50^{\circ} \mathrm{C}$. The residue was dissolved in $5 \mathrm{~mL}$ loading buffer $(0.2 \mathrm{~N}$ sodium citrate buffer of pH 2.2. Beckman Amino Acid Analyzer (Model119CL) was used for determination of amino acids composition.

\section{Fatty acid composition analysis using HPLC}

Fatty acid methyl esters were separated from the total lipids using $5 \mathrm{~mL}$ of $3 \% \mathrm{H}_{2} \mathrm{SO}_{4}$ in absolute methanol and $2 \mathrm{~mL}$ benzene as described by Rossell et al. (1983). The mixture was heated at $90^{\circ} \mathrm{C}$ for $90 \mathrm{~min}$, cooled to room temperature, and phase separation was performed by addition of $2 \mathrm{~mL}$ water.The methyl esters were extracted with aliquots of $5 \mathrm{~mL}$ hexane. The organic phase was removed, filtrated through anhydrous sodium sulfate, and concentrated using a rotary evaporator. The fatty acids methyl esters were separated by Perkin-ElmarGasChromatography (model F22) with a flame ionization detector in presence of nitrogen as a carrier gas. A glass column packed with diethylenglyco succinate (DEGS) on chromosorb W 80- 100 mesh was used. Injector and detector temperature was $220^{\circ} \mathrm{C}$. The nitrogen, hydrogen and air flow rate were 30,30 , and $300 \mathrm{~mL} / \mathrm{min}$, respectively. The chart speed was $1 \mathrm{~cm} / \mathrm{min}$. Peaks identification were established by comparing the retention times obtained with standard methyl esters of fatty acidsas described by Kates (1972).

\section{Statistical analysis}

The statistical analysis of data was performed by Analysis of Variance (ANOVA) and the results were subjected to Duncan's test. Significance level of $\mathrm{p}<0.05$ was used.

\section{$\underline{\text { Results and Discussion }}$}

\section{Body composition and carcass characteristics}

Body weight of live chickens and weight of body parts after slaughter are presented in Table 1 as a percentage of the live body weight. The body weight of live chicken was found to be in range from 2110 to $2357 \mathrm{~g}$. However, the percentage of dressed carcass was found to be $93.41 \%$ of the live body weight. On the other hand, the eviscerated carcass showed a mean weight percentage of $77.28 \%$ of the live body weight. Liver, gizzard, wings, and skin showed percentages of 2.35, $1.86,7.22$, and $6.68 \%$ of the live body weight, respectively. The mean weight of eviscerated carcass and weight of body parts as a percentage of eviscerated carcass are presented in Table 2. The greatest percentage was found for breast, followed by thigh, and drumstick; while the lowest percentage was found for giblets. However, the greatest percentage was found for wings and the lowest was found for gizzard among the main studied by-products, including liver, gizzard, wings and skin. Carcass composition of broiler was found to be influenced by different factors such as diet, age, sex and genotype (Abdalla et al., 1999). In one study, Bimbo (2005) found that by-products count about $37 \%$ of the live broiler chicken weight. In another study, Fereidoun et al. (2007) found that chicken skin represents between 8 and $20 \%$ of the total weight. Moreover, Ojedapo et al. (2008) found that strain and sex significantly affect body weight of chicken. Furthermore, Almasi, et al. (2012) found that the yield of male chickens (70- 84 days) was about $68.20-70.90 \%$; while, the yield of female chicken (70- 84 days) was about $68.40-68.00 \%$. Our results are also in a good agreement with the findings of Dariusz et al. (2013); Kokoszynski et al. (2013); Abdullah and Buchtova (2016); and Musundire et al. (2018).

\section{Gross chemical composition}

Gross chemical composition and caloric value of edible chicken by-products including, liver, gizzard, wings, and skin were determined,and the results are presented in Table 3. From the results it can be noticed that the gizzard contains the greatest moisture content, followed by liver, and wings; while skin contains the lowest moisture content. On the other hand, wings contain the greatest protein content and skin contains the lowest protein content. The differences in protein contentof the varying chicken by-products may be attributed that they are constituted ofdifferent typesand quantities of proteins (Seong et al., 2015). However, skin containsthe highest fat content and gizzardcontains the lowest protein content. Moreover, the ash content was found to be in the order liver $>$ gizzard $>$ wings $>$ skin. Furthermore, the greatest caloric value (362.36 K $\mathrm{Cal} / 100 \mathrm{~g}$ ) was found for skin and the lowest value (89.74 K Cal/100g) was found for gizzard. These findings agree with the results of Abu-Salem and Abou Arab (2010) who found $66.80 \%$ moisture, 
$24.60 \%$ protein, $6.00 \%$ fat, and $1.40 \%$ ash in raw chicken liver. In another study, Kumar and Rani (2014) found that chicken wings had contained moisture of $68.57-69.64 \%$, protein $16.57-18.32 \%$, and fat of $12.16-13.41 \%$. Moreover, Wani and Majeed (2014) found that raw chicken gizzard had contained moisture of $76.60 \%$, ash of 0.64
$\%$, protein of $19.69 \%$, and of fat of $2.15 \%$. Furthermore, Farmani and Rostammiri (2015) found that chicken skin had contained moisture of $50.78 \%$, protein of $8.93 \%$, fat of $38.92 \%$, and ash of $1.28 \%$. Our results are also in good agreement with those found by Seong et al. (2015) and Abdullah and Buchtova (2016).

TABLE 1. Body weight and body composition ( $\%$ of live weight).

\begin{tabular}{cccc}
\hline Body parts & $\begin{array}{c}\text { Average weight of live } \\
\text { chicken }(\mathbf{g})(\mathbf{n}=\mathbf{1 0})\end{array}$ & Weight range (g) & $\begin{array}{c}\text { \% of live body } \\
\text { weight }\end{array}$ \\
\hline live weight & $2255.78 \pm 92.98$ & $2110.00-2357.00$ & 100 \\
After slaughter & $2196.11 \pm 103.33$ & $2035.00-2313.00$ & 97.35 \\
Blood & $59.67 \pm 11.88$ & $42.00-79.00$ & 2.65 \\
Feather & $89.00 \pm 19.84$ & $54.00-113.00$ & 3.95 \\
Dressed carcass & $2107.11 \pm 96.95$ & $1940.00-2218.00$ & 93.41 \\
Head & $39.84 \pm 2.65$ & $37.50-46.04$ & 1.77 \\
Neck & $91.06 \pm 11.67$ & $66.15-104.47$ & 4.04 \\
Viscera & $136.26 \pm 14.10$ & $114.08-157.31$ & 6.04 \\
Feet & $83.04 \pm 6.33$ & $74.46-97.44$ & 3.63 \\
Eviscerated Carcass $*$ & $1743.18 \pm 86.56$ & $1619.60-1880.63$ & 77.28 \\
Breast & $804.19 \pm 60.59$ & $706.40-911.36$ & 35.65 \\
Thigh & $542.52 \pm 52$ & $487.74-585.94$ & 24.05 \\
Drumstick & $234.86 \pm 16.74$ & $192.75-248.52$ & 10.41 \\
Giblets** & $105.69 \pm 19.68$ & $85.30-141.03$ & 4.69 \\
Heart & $10.80 \pm 1.05$ & $9.24-12.73$ & 0.48 \\
Liver & $52.97 \pm 11.60$ & $42.89-81.81$ & 2.35 \\
Gizzard*** & $41.92 \pm 7.04$ & $28.98-53.81$ & 1.86 \\
Wings & $162.90 \pm 18.23$ & $129.49-183.10$ & 7.22 \\
Skin & $150.63 \pm 17.49$ & $124.77-182.30$ & 6.68 \\
\hline
\end{tabular}

*weight of carcass with giblets and without neck, feet, head and neck; ** Liver, gizzard and heart; *** with opening.

TABLE 2. Chicken carcass yield and cut-up parts (\% of carcass weight)."

\begin{tabular}{lc}
\hline Parameters & \% of eviscerated carcass weight \\
\hline Eviscerated Carcass yield & $77.28 \pm 0.96^{\mathrm{a}}$ \\
Breast percent & $46.13 \pm 2.42^{\mathrm{b}}$ \\
Thigh percent & $31.12 \pm 1.54^{\mathrm{c}}$ \\
Drumstick percent & $13.47 \pm 0.88^{\mathrm{d}}$ \\
Giblets percent & $6.06 \pm 0.85^{\mathrm{g}}$ \\
Heart percent & $0.62 \pm 0.05^{\mathrm{j}}$ \\
Liver percent & $3.04 \pm 0.61^{\mathrm{h}}$ \\
Gizzard percent & $2.41 \pm 0.35^{\mathrm{i}}$ \\
Wings percent & $9.34 \pm 0.81^{\mathrm{e}}$ \\
Skin percent & $8.64 \pm 1.07^{\mathrm{f}}$ \\
\hline
\end{tabular}

*Different subscript letters within the same column indicate significant difference $(p<0.05)$.

Egypt. J. Food. 47, No.1 (2019) 
TABLE 3. proximate chemical composition of some chicken by-products (wet weight basis).

Chicken by-products

Constituents

\begin{tabular}{|c|c|c|c|c|}
\hline & Liver & Gizzard & Wings & Skin \\
\hline Moisture & $73.31 \pm 0.05^{\mathrm{b}}$ & $76.62 \pm 0.27^{\mathrm{a}}$ & $61.42 \pm 1.16^{\mathrm{c}}$ & $52.80 \pm 0.09^{\mathrm{d}}$ \\
\hline Protein & $18.20 \pm 0.30^{\mathrm{c}}$ & $19.60 \pm 0.25^{\mathrm{b}}$ & $26.33 \pm 1.01^{\mathrm{a}}$ & $13.01 \pm 0.21^{\mathrm{d}}$ \\
\hline Fat & $4.36 \pm 0.01^{\mathrm{c}}$ & $1.26 \pm 0.11^{\mathrm{d}}$ & $14.84 \pm 0.44^{\mathrm{b}}$ & $34.48 \pm 0.18^{\mathrm{a}}$ \\
\hline Ash & $1.42 \pm 0.01^{\mathrm{a}}$ & $0.91 \pm 0.01^{\mathrm{b}}$ & $0.83 \pm 0.02^{\mathrm{c}}$ & $0.46 \pm 0.01^{\mathrm{d}}$ \\
\hline Caloric value (KCal/100g) & $114.2 \pm 0.40^{\mathrm{c}}$ & $89.74 \pm 0.08^{\mathrm{d}}$ & $238.88 \pm 0.37^{b}$ & $362.36 \pm 0.01^{\mathrm{a}}$ \\
\hline
\end{tabular}

*Different subscript letters within the same raw indicate significant difference $(p<0.05)$.

\section{Minerals content}

Minerals contentsof liver, gizzard, wings, and skin were determined, and the results are presented in Table 4. Generally, these edible chicken byproducts showed greater contents of phosphorus (P) and potassium $(\mathrm{K})$, followed by sodium $(\mathrm{Na})$, magnesium $(\mathrm{Mg})$, and calcium $(\mathrm{Ca})$. The minerals content was found to different among the chicken by-products. For example, wings showed greatest content of $\mathrm{P}$, followed by skin and liver; while, the gizzard showed the lowest content of P. Also, these by-products trend of $\mathrm{K}$ content similar to that of P. On the other hand, the liver showed the greatest content of iron $(\mathrm{Fe})$, followed by wings and gizzard; however, skin showed the lowest Fe content. Also, liver showed the greatest content of zinc ( $\mathrm{Zn}$ ) among the studied chicken by-products. These results indicate that the studied edible by-products of chicken are a good source of minerals for the human body. It was reported that the interest in by-products of meat is influenced by their protein, vitamins, and minerals contents(Benoist, 2001). Trace element such as zinc $(\mathrm{Zn})$, iron $(\mathrm{Fe})$, manganese $(\mathrm{Mn})$, and copper $(\mathrm{Cu})$ are vital for the human well-being (Tapiero and Tew, 2003). Theobtained results are consistent with findings of previous studies. For example, Abu-Salem and Abou Arab (2010) found that chicken liver contained $\mathrm{Fe}$ of 83.65, Zn of 50.75 , and of Mn $1.15 \mathrm{mg} / \mathrm{g}$ (wet weight basis). Also, Farmani and Rostammiri (2015) found that chicken skin contained phosphorous of 13.43 and Iron of 35.39 ppm.Moreover, mineral contents of liver and gizzard are in agreement with those found by Seong et al. (2015) and Abdullah and Buchtova (2016).

TABLE 4. Minerals content of some chicken by-products ( $\mathrm{mg} / 100 \mathrm{~g}$ wet weight basis).

\begin{tabular}{|c|c|c|c|c|}
\hline \multirow{2}{*}{ Minerals } & \multicolumn{4}{|c|}{ Chicken by-products } \\
\hline & Liver & Gizzard & Wings & Skin \\
\hline $\mathrm{Ca}$ & 14.36 & 14.43 & 18.34 & 5.07 \\
\hline $\mathrm{P}$ & 258.33 & 183.08 & 306.04 & 298.28 \\
\hline $\mathrm{K}$ & 235.81 & 191.58 & 306.09 & 244.49 \\
\hline $\mathrm{Na}$ & 79.41 & 52.86 & 114.26 & 146.66 \\
\hline $\mathrm{Mg}$ & 22.58 & 10.80 & 23.39 & 27.19 \\
\hline $\mathrm{Fe}$ & 12.93 & 5.55 & 7.74 & 4.51 \\
\hline $\mathrm{Zn}$ & 5.99 & 2.38 & 2.16 & 3.28 \\
\hline $\mathrm{Mn}$ & 0.33 & 0.15 & 0.13 & 0.92 \\
\hline
\end{tabular}




\section{Amino acids composition}

Amino acidscontents ofthe studied edible by-products of chicken, including liver, gizzard, wings, and skin were determined and the results are presented in Table 5. The liver showed the greatest total essential amino acids content, followed by wings, gizzard, and skin. Generally, leucine and lysine are the predominant among essential amino acids in these chicken byproducts. The greatest leucine content was found in liver; while, the greatest lysine content was found for wings. The total non-essential amino acids content was found to be in the order skin $>$ wings $>$ gizzard $>$ liver. Glutamic acid is the most predominant among the non-essential amino acids in the studied by-products. These results revealed that liver, wings, gizzard, and skin of chicken are a good source of amino acids needed for the human body. The human body is not able to produce the essential amino acids (EAAs) and only can obtain them form diet. This is because the absence of these essential amino acids significantly influences physiological functions of the human body ( $\mathrm{Wu}, 2010)$. The amino acids profile isconsistent with findings of previous studies. For example, Sarbon et al. (2013) found that Gly, Pro, H.Pro, and Ala were the predominant amino acids in gelatin of chicken skin. The essential amino acids content is also in agreement with thatfound by Adeyeyeand Olayinka Ibigbami (2013). Moreover, Seong et al. (2015) found that leucine and lysine are the predominant essential amino acids (EAAs) in by-products of chicken. They also found the greatest levels of EAAs in liver, followed by gizzard and heart. In addition, duodenum and heart showed the greatest total EAAs/total amino acids ratio, followed by liver. Furthermore, Kim et al. (2017) found that EAAs contents (g/ 100 g) of chicken wings were Arg 1.09, His 0.47, Ile 0.78, Leu 1.42, Lys 1.43, Met 0.44, Phe 0.73, Thr 0.77 and Val 0.80 .

TABLE 5. Amino acid composition (g/100g crude protein) of some edible by-products of chicken (dry weight basis).

\begin{tabular}{|c|c|c|c|c|}
\hline \multirow{2}{*}{ Amino acid } & \multicolumn{4}{|c|}{ Chicken by-products } \\
\hline & Liver & Gizzard & Wings & Skin \\
\hline Threonine & 4.38 & 3.98 & 3.90 & 4.34 \\
\hline Valine & 6.31 & 4.50 & 4.37 & 4.41 \\
\hline Methionine & 2.71 & 2.73 & 2.62 & 2.14 \\
\hline Isoleucine & 4.78 & 3.59 & 4.16 & 3.31 \\
\hline Leucine & 8.64 & 6.48 & 6.96 & 6.15 \\
\hline Phenylalanine & 4.49 & 3.69 & 3.79 & 3.58 \\
\hline Lysine & 5.92 & 6.17 & 7.49 & 6.20 \\
\hline Total essential amino acids & 37.23 & 31.14 & 33.29 & 30.19 \\
\hline Histidine & 2.33 & 2.14 & 2.96 & 1.64 \\
\hline Arginine & 6.04 & 6.45 & 6.51 & 7.13 \\
\hline Aspartic & 8.29 & 7.73 & 8.50 & 8.13 \\
\hline Serine & 4.19 & 3.83 & 3.49 & 3.22 \\
\hline Glutamic & 12.29 & 13.99 & 14.27 & 12.68 \\
\hline Proline & 4.12 & 5.13 & 4.89 & 7.30 \\
\hline Alanine & 6.50 & 6.13 & 6.48 & 7.15 \\
\hline Cysteine & 1.73 & 1.40 & 1.86 & 2.12 \\
\hline Tyrosine & 3.46 & 3.30 & 3.24 & 2.43 \\
\hline Glycine & 4.71 & 6.93 & 7.14 & 11.27 \\
\hline Total non- essential amino acids & 53.66 & 57.03 & 59.34 & 63.07 \\
\hline Total amino acid & 90.89 & 88.17 & 92.63 & 93.20 \\
\hline E/NE ratio & 0.69 & 0.55 & 0.56 & 0.48 \\
\hline
\end{tabular}

Egypt. J. Food. 47, No.1 (2019) 


\section{Fatty acids composition}

Fatty acids contents of chicken liver, gizzard, wings, and skin were determined, and the results are presented in Table 6 . These by-products showed greater total unsaturated fatty acids content than that of total saturated fatty acids content. Oleic acid followed by $\square$-linoleic acid and $\square$-linolenic acid are the predominant unsaturated fatty acids found in these by-products. However, palmitic and stearic acids are the most predominant saturated fatty acids found in liver, gizzard, wings, and skin of chicken. Also, these by-products showed a good content of arachidonic acid. The obtained results revealed that these by-products are a good source of essential and unsaturated fatty acids, which are important for the human health and well-being. It was reported that the dietary fatsconsumptionis associated to obesity and chronic diseases such as cardiovascular disease and diabetes Jump, 2002).Therefore, World Health Organization (WHO) and Food and Agriculture Organization (FAO) recommended that adults should intake $20-35 \%$ of diet energy of total fat, less than $10 \%$ of saturated fatty acids, 15 $20 \%$ of monounsaturated fatty acids, and $6-11 \%$ of poly unsaturated fatty acids (Burlingame et al., 2009). The fatty acids profile found in this study is consistent with findings of previous studies. For example, Farmani and Rostammiri (2015) found that chicken waste fat contained $30.70 \%$ saturated fatty acids, $38.22 \%$ monounsaturated fatty acids, and $30.90 \%$ polyunsaturated fatty acids. Also, Méndez-Lagunas, et al. (2015) found that skin of chicken showed palmitic acid content of $20.76 \%$, stearic acid content of $6.46 \%$, and oleic acid content of $57.54 \%$.Moreover, the fatty acids profile composition and contents of liver and gizzard are in agreement with findings of Seong et al. (2015). It was reported that the recommendations for n-6/n-3 fatty acids ratio for the healthy diet as a whole should be 4.0 or lower; while, the PUFA/ SFA ratio should be 0.40 or higher(Department of Health, 1994).

TABLE 6. Fatty acid composition of total lipids of some edible by-products of chicken (\% of total fatty acids).

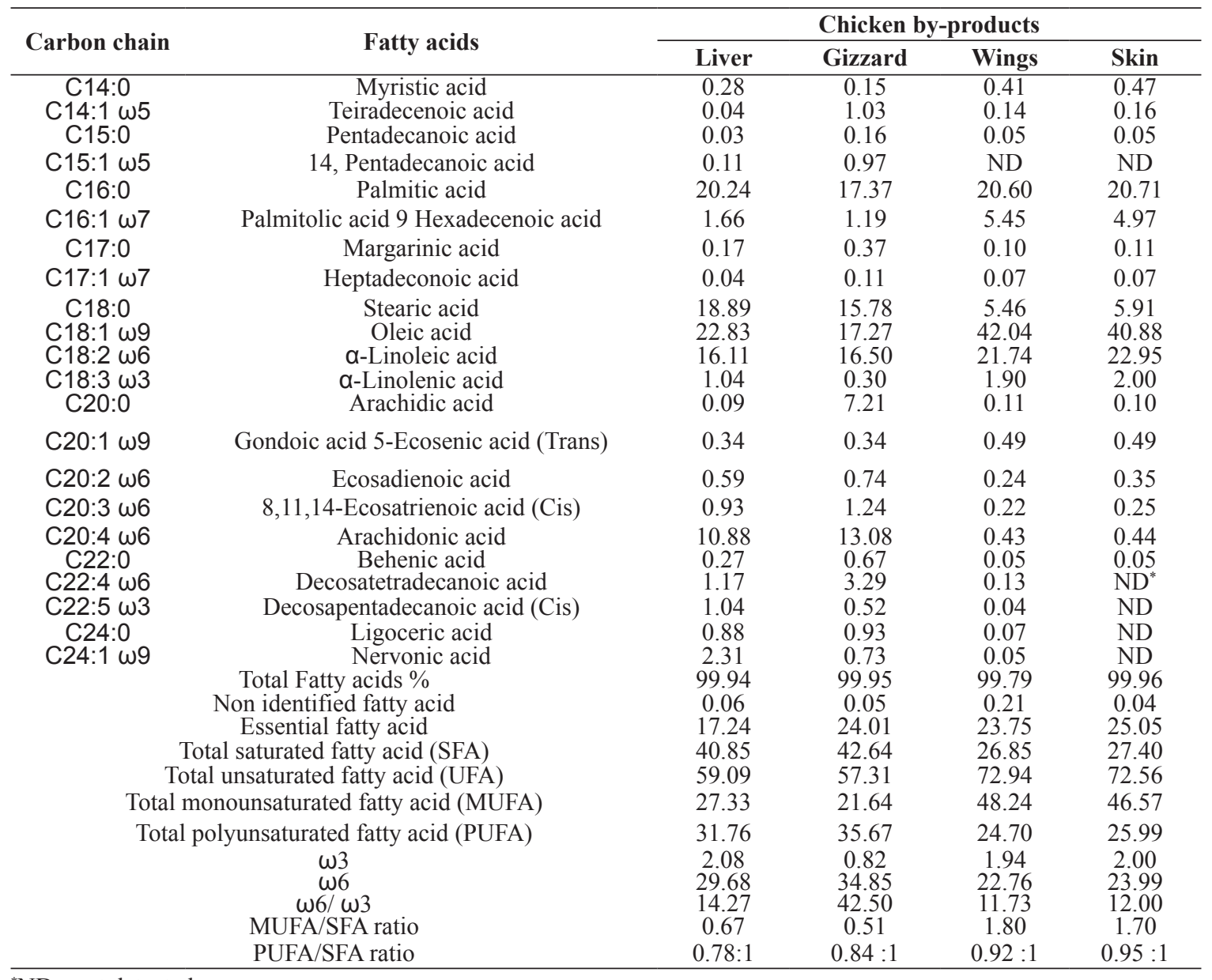

${ }^{*} \mathrm{ND}=$ not detected 


\section{Conclusion}

Nutrients composition of some chicken edible by-products, including liver, gizzard, wings, and skin was analyzed. The total yield of these chicken by-products was found to be about $23.43 \%$ of carcass weight. The studied chicken by-products contained appreciable amounts of protein, fat, and ash. The level of protein, fat, and ash varied significantly $(P<0.5)$ among different chicken by-products. The greatest protein content was found for wings; while, the greatest fat content was found for skin, and the liver showed the greatest ash content among the studied chicken by-products. On the other hand, liver, gizzard, wings, and skin of chicken were found to be a good source of minerals such as potassium, phosphorus, sodium, iron, and zinc. In addition, these chicken by-products were found to be good sourcesof essential amino acids such as leucine and lysine. Furthermore, the level of total unsaturated fatty acids was found to be greater than that of the total saturated fatty acids in the studied chicken by-products.

\section{Acknowledgement}

This work was supported by Earmarked Research Fund for the Department of Food Science and Technology, Faculty of Agriculture, Assiut University, Egypt.

\section{Conflict of Interest}

The authors declare that there is no conflict of interest.

\section{References}

A.O.A.C. (1995) Official Methods of Analysis of the Association of Official Analytical Chemistry. $16^{\text {th }}$ ed., AOAC International, Washington, USA. P. 1141.

A.O.A.C. (2000) Official Methods of Analysis. 17 $7^{\text {th }}$ ed. Washington, D.C: Association of Official Analytical Chemist.

Abdullah, F. A. A. and Buchtova, H.(2016) Comparison of qualitative and quantitative properties of the wings, necks and offal of chicken broilers from organic and conventional production systems. Veterinarni Medicina, 61 (11), 643-651.

Abu-Salem, M. F. and Abou Arab, A. E. (2010) Chemical properties, microbiological quality and sensory evaluation of chicken and duck liver paste (foie gras). GrasasYAceites, 61 (2), 126-135.

Egypt. J. Food. 47, No.1 (2019)
Adeyeye, I. E. and OlayinkaIbigbami, A. (2013) Amino Acids Profile of the Organ Meats of the Turkey-hen (Meleagris gallopavo). Research \& Reviews: $J$. Food Dairy Technol., 1 (1), 1-7.

Abdalla. S. A., Ali, P. A., and Jensen, J.F. (1999) Effect of ante-mortem stressors on peri-mortem and postmortem biochemical changes and tenderness in broiler breast muscle. World's Poult. Sci. J.,55 (4), 403-414.

Almasi A., Zoltan,S., Budai, Z., Donko, T., Milisits, G., and Horn, P. (2012) Effect of age, sex and strain on growth, body composition and carcass characteristics of dualpurpose type chicken. World's Poultry Science Journal,Expanded Abstract - Oral Presentation - Genetics and Breeding,(WPC2012) - Salvador - Bahia - Brazil - 5 - 9 August, Book of Abstracts (GB_2012pc538_1). World's Poult. Sci. $J$., Supplement 1, 47-50.

Alvarez-Astorga M., Capita, R., Alonso-Calleja, C., Moreno, B., and Garcia-Fernandez, C. (2002) Microbiological quality of retail chicken byproducts in Spain. Meat Sci., 62, 45-50.

Benoist, B. (2001) Deficiency anemia: Reexamining the nature and magnitude of the public health problem; Introduction. The Journal of Nutrition, 131 (2), 564S.

Bimbo, A. P. (2005) Rendering. Industrial and Nonedible Products from Oils and Fats. In: Shahidi $\mathrm{F}$, Editor. Bailey's industrial oil and fats products. (6th ed.). Hoboken, NJ: John Wiley and Sons, Inc.; (6), 64-65, 76-77.

Bolan, N. S., Szogi, A.A., Chunasauth, T., seshacri, B., Rothrock, M. J., panne, E. R., and Selvam, P. (2010) Uses and Management of poultry litter. World's Poult. Sci. J.,66 (4), 673-698.

Burlingame, B., Nishida, C., Uauy, R., and Weisell, R. (2009)Fats and fatty acids in human nutrition (Report of a joint FAO/WHO Export Consultation). Annals of Nutrition and Metabolism, 55, 1-380.

Charoenpong, C., and Chen, T. C. (1980) Qualities of pickled chicken gizzards as affected by salt and vinegar. Poult. Sci., 59, 537-542.

Chouliara, E., Karatapanis, A., Savvaidis, I. N., and Kontominas, M. G. (2007) Combined effect of oregano essential oil and modified atmosphere packaging on shelf-life extension of fresh chicken breast meat, stored at 4C.Food Microbiol., 24 (6), 607-617. 
Dariusz, K., Zenon, B., Henryka, K., Krzysztof, K., and Lidia, S. (2013) Carcass composition and physicochemical and sensory properties of meat form broiler chicken of different origin. Journal of Central European Agriculture, 14 (2), 303-315.

Department of Health. (1994) Nutritional aspects of cardiovascular disease (report on health and social subjects no 46). London UK: HMSO.

FAO (2017) Broiler poultry industry: investment challenges and opportunities. p. 14

FAO (2018) Food Outlook. Biannualreporton globalfoodmarkets. July 2018. P. 7

FAO (2018) Food Outlook. Biannual report on global food markets. July 2018. Meat and meat products, $48-49$.

Farmani J. and Rostammiri, L.(2015) Characterization of chicken waste fat for application in food technology. J. Food Meas.Charact., 9 (2), 143-150.

Fereidoun H., Bahram, A., Sadraddin, K. S., Abbass, A., and Pouria, H. (2007)Mean Percentage of Skin and Visible Fat in 10 Chicken Carcass Weight. $J$. Poult. Sci., 6 (1), 43-47.

Fletcher, D. L. (2002) Poultry meat quality. World's Poult. Sci. J.,58(2), 131-145.

Jump, D. B. (2002) The biochemistry of n-3 polyunsaturated fatty acids. J. Biol.Chem., 277, 8755-8758.

Kates, M. (1972) Techniques of lipidology. Isolation, Analysis and Identification of lipids. North Holland publishing Co, Amsterdam.

Kim, H., Hyun, W. D., and Chung, H. (2017) A Comparison of the Essential Amino Acid Content and the Retention Rate by Chicken Part according to Different Cooking Methods. Korean J. Food Sci. Anim. Resour, 37(5), 626-634.

Kokoszynski D., Bernacki, Z., Korytkowska, H., Krajewski, K., and Skrobiszewska, L. (2013) Carcass composition and physicochemical and sensory properties of meat from broiler chickens of different origin. Journal of Central European Agriculture, 14 (2), 303-315.

Kumar, P. R., and Rani, S. M. (2014) Chemical composition of chicken of various commercial brands available in market. Journal of Agriculture and Veterinary Science, 7, 22-26.
Méndez-Lagunas, L. L., Siles-Alvarado, S., RodríguezRamírez, J., and Aquino-Gonzále, A. L. (2015) Fatty Acid Profile Composition of Chicken Skin. International Journal of Chemical and Biomolecular Science, 1 (3), 193-196.

Mohamed, H.A. (2005) Low fat products as prepared from ostrich and other produced fat beef. (Ph.D. Thesis), Nutrition and Food Science. Dept. Faculty of Home Economics. Minofia University. Egypt.

Mountney, G.J., and Parkhurst, C.R. (2001) Poultry Products Technology. 1st ed. Viva Books Pvt. Ltd., New Delhi.

Mulder, N. D. (2011) Global Meat Demand 2010 2030, Presentation by Nan-Dirk Mulder, Rabobank International, presentation at International Poultry Council Meeting, Rome, April 2011.

Musundire, T. M., Edward, T., and Chimonyo, M.(2018) Effect of age and sex on carcass characteristics and internal organ weights of scavenging chickens and helmeted guinea fowls. J. Appl. Anim. Res., 46 (1), 860-867.

Nollet, L. M. L., and Toldrá, F.(2011) Introduction of Offal meat: Definitions, regions,cultures, generalities. In: Handbook of Analysis of Edible Animal By-Products. Nollet, L.M. L. and Toldrá, F. (Ed.) CRC Press (Chemical Rubber Company), Boca Raton, Florida, USA, 3-11.

Ockerman, H. W. and Basu, L. (2004) By-products. In: Encyclopedia of Meat Sciences. Jensen, W. K., Devine, C., and Dikeman, M (eds) Elsevier Academic Press, Amsterdam, London, p. 104-112.

Ojedapo, L.O., Akinokun, O., Adedeji, T.A., Olayeni, T.B., Ameen, S.A., and Amao, S.R. (2008) Effect of Strain and Sex on Carcass Characteristics of Three Commercial Broilers Reared in Deep Litter System in the Derived Savannah Area of Nigeria. World J. Agric. Sci., 4, 487-491.

Pellett, P. L. and Young, V. R. (1980) Nutritional evaluation of protein foods. Food and Nutrition Bulletin, Geneva - Switzerland, Food and Agriculture Organization of the United Nations (Suppl. 4): 4-101.

Rossell, J. B., King, B., and Downes, M. J. (1983) Detection of adulteration. J. Am. Oil Chem. Soc., 60 (2), 333-339.

Sarbon, M. N., Badii, F., and Howell, K. N. (2013) Preparation and characterization of chicken skin gelatin as an alternative to mammalian gelatin. Food Hydrocoll., 30, 143-151.

Egypt. J. Food. 47, No.1 (2019) 
Seong, P. N., Cho,S. H., Park,K. M., Kang, G. H., Park,B. Y., Moon,S. S. and Ba, H. V. (2015) Characterization of chicken by-products by mean of proximate and nutritional compositions. Korean J. Food Sci. Anim.Resour.,35 (2), 179-188.

Tapiero, H. and Tew, K. D. (2003) Trace elements in human physiology and pathology: Zinc and metallothioneins. Biomed. Pharmacother, 57, 399411.

Toldra, F., Aristoy, M. C., Mora,L., and Reig, M. (2012) Innovations in value-addition of edible meat byproducts. Meat Sci., 92,290-296.
Valsta, L. M., Tapanainen, H, and Mannisto, S. (2005) Meat fats in nutrition. Meat Sci.,70 (3), 525-30.

Wani, S.A, and Majeed, D. (2014) Evaluation of quality attributes and storage stability of pickle prepared from chicken gizzard. J. Meat Sci. Technol., 2 (4), 85-89.

Wu, G. (2010) Functional amino acids in growth, reproduction, and health. Adv.Nutr., 1, 31-37.

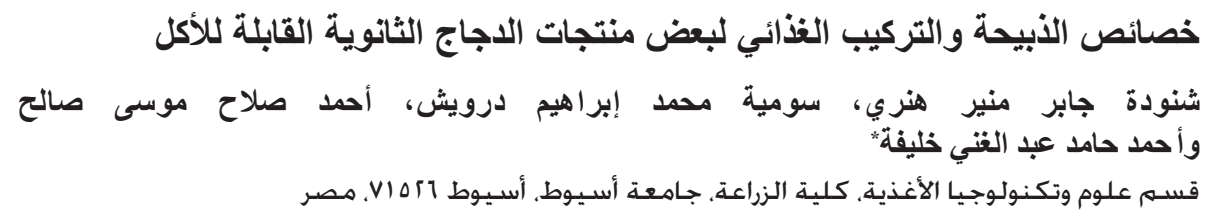

كان الهدف من هذا العمل هو دراسة خصائص ذبيحة الدجاج وتقدير التركيب الغذائي لبعض منتجات الدجاج

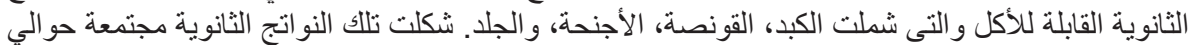

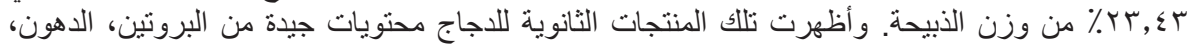

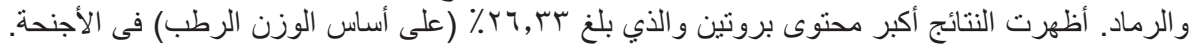

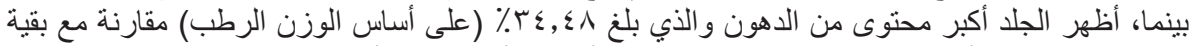

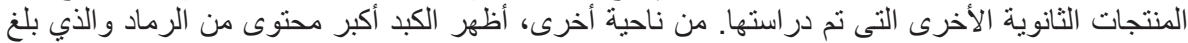

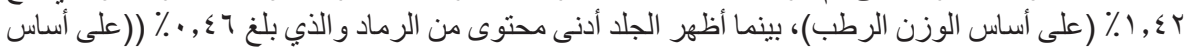

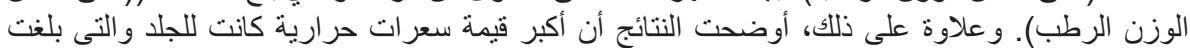

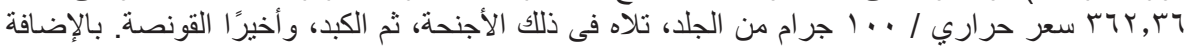

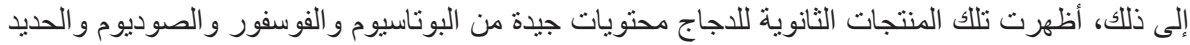

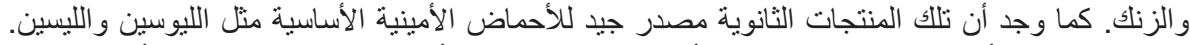

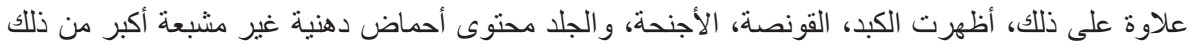

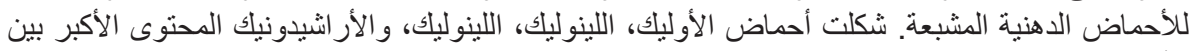

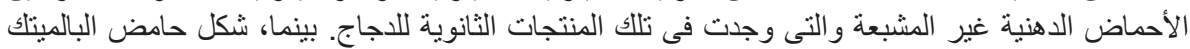

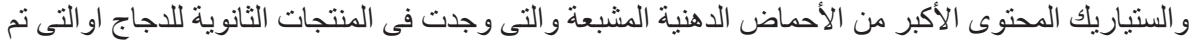

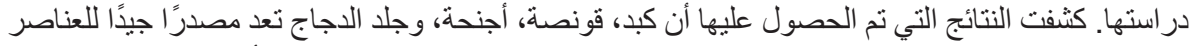

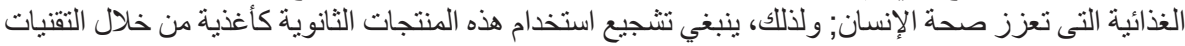
المتطورة لتجهيز منتجات غذائية مختلفة من اللحوم. 